Acknowledgments. The authors thank Randy Jerkins, Patti Jessup, and Mildred Jackson for their expert technical help and Rosalind Griffin for secretarial assistance.

\section{REFERENCES}

1. Alexander JM, Nyby MD, Jasberg KA 1977 Prostaglandin synthesis inhibition restores hypoxic pulmonary vasoconstriction. J Appl Physiol Respir Environ Exercise Physiol 42:903

2. Gerber JG, Voelkel N, Nies AS, McMurtry IF, Reeves JT 1980 Moderation of hypoxic vasoconstriction by infused arachidonic acid: role of $\mathrm{PGI}_{2}$. J Appl Physiol Respir Environ Exercise Physiol 49:107

3. Green R, Rojas J, Sundell H 1979 Pulmonary vascular response to prostacyclin in fetal lambs. Prostaglandins 18:927

4. Hamasaki Y, Tai H, Said SI 1982 Hypoxia stimulates prostacyclin generation by dog lung in vitro. Prostaglandins Leukotrienes Med 8:311

5. Hyman AL, Bennett JT, Joiner PD, Chapnick BM, Mathe A, Kadowitz PJ 1976 Pulmonary vascular responses to arachidonic acid in intact dogs. Clin Res 24:53

6. Hyman AL, Mathe AA, Leslie CA, Mathews CC. Bennett JT, Spannhake E, Kadowitz PJ 1978 Modification of pulmonary vascular responses to arachidonic acid by alterations in physiologic state. J Pharmacol Exp Ther 207:388

7. Kadowitz PJ, Gruetter CA. McNamara DB, Gorman RR, Spannhake EW, Hyman AL 1977 Comparative effects of endoperoxide $\mathrm{PGH}_{2}$ and an analog on the pulmonary vascular bed. J Appl Physiol Respir Environ Exercise Physiol 42:953

8. Leffler CW, Desiderio DM, Wakelyn CE 1981 Preparation of biological fluids for simultaneous analysis of prostaglandin cyclooxygenase synthesized compounds by gas chromatography with electron capture detection. Prostaglandins $21: 227$

9. Leffler CW. Hessler JR 1979 Pulmonary and systemic vascular effects of exogenous prostaglandin $I_{2}$ in fetal lambs. Eur $J$ Pharmacol 54:37

10. Leffler CW. Hessler JR 1981 Perinatal pulmonary prostaglandin production. Am J Physiol 241:H756

11. Leffler CW, Hessler JR, Terragno NA 1980 Ventilation-induced release of prostaglandinlike material from fetal lungs. Am J Physiol 238:H282

12. Leffler CW, Passmore JC 1979 Contribution of prostaglandins to the regulation of pulmonary vascular resistance in adult cats and dogs. Prostaglandin Med 3:343

13. Lock JE. Olley PM, Coceani F 1980 Direct pulmonary vascular responses to prostaglandins in the conscious newborn lamb. Am J Physiol 238: H631

14. Moon MA, Lemen RJ, Quan SF 1983 Failure of acute hypoxia to alter pulmonary prostaglandin metabolism in dogs. Prostaglandins 25:615

15. Mullane KM, Dusting GJ, Salmon JA, Moncada S, Vane J 1979 Biotransformation and cardiovascular effects of arachidonic acid in the dog. Eur J Pharmacol 54:217

16. Powell WS 1980 Rapid extraction of oxygenated metabolites of arachidonic acid from biological samples using octadecylsilyl silica. Prostaglandins 20:947

17. Rubin LJ, Lazar JD 1981 Influence of prostaglandin synthesis inhibitors on pulmonary vasodilatory effects of hydralazine in dogs with hypoxic pulmonary vasoconstriction. J Clin Invest 67:193

18. Said SI, Yoshida T, Kitamura S, Vreim C 1974 Pulmonary alveolar hypoxia: release of prostaglandins and other humoral mediators. Science 185:1181

19. Scott E, Vaage J, Wiberg T 1979 Lack of release of prostaglandins from isolated perfused lungs during pulmonary hypertension and oedema. $\mathrm{Br} \mathrm{J}$ Pharmac 65:197

20. Snedecor GW, Cochran WG 1980 Statistical Methods, 7th ed. Iowa State University Press, Ames, pp 256-257

21. Spannhake EW, Hyman AL, Kadowitz PJ 1980 Dependence of the airway and pulmonary vascular effects of arachidonic acid upon route and rate of administration. J Pharmacol Exp Ther 212:584

22. Terragno NA, McGiff JC, Smigel M. Terragno A 1978 Patterns of prostaglandin production in the bovine fetal and maternal vasculature. Prostaglandins 16:847

23. Tyler T, Wallis R, Leffler C, Cassin S 1975 The effects of indomethacin on the pulmonary vascular response to hypoxia in the premature and mature newborn goat. Proc Soc Exp Biol Med 150:695

24. Vaage J. Bjertnaes J, Hauge A 1975 The pulmonary vasoconstrictor response to hypoxia: effects of inhibitors of prostaglandin biosynthesis. Acta Physiol Scand 95:95

25. Vaage J, Wiberg T, Bjertnaes L, Hauge A. Teig V, Gautvik K 1976 The effect of alveolar hypoxia on pulmonary biosynthesis of prostaglandins. Acta Physiol Scand Suppl 440:172

26. Voelkel NF, Gerber JG, McMurtry IF, Nies AS, Reeves JT 1981 Release of vasodilator prostaglandin $\mathrm{PGI}_{2}$ from isolated rat lung during vasoconstriction. Circ Res 48:207

27. Weir EK, McMurtry IF, Tucker A, Reeves JT, Grover RF 1976 Prostaglandin synthetase inhibitors do not decrease hypoxic pulmonary vasoconstriction. J Appl Physiol 41:714

28. Weir EK, Reeves JT, Grover RF 1974 Meclofenamate and indomethacin augment the pulmonary pressor response to hypoxia and exogenous prostaglandin $F_{2 \alpha}$. Physiologist 17:355

29. Wiberg T, Vaage J, Bjertnaes J, Hauge A, Gautvik KM 1978 Prostaglandin content in blood and lung tissue during alveolar hypoxia. Acta Physiol Scand $102: 181$

\title{
Vasopressin Concentration in Amniotic Fluid as an Index of Fetal Hypoxia: Mechanism of Release in Sheep
}

\author{
RAYMOND I. STARK, SALHA S. DANIEL, M. KAZIM HUSAIN, ULANA M. SANOCKA, \\ ALAN B. ZUBROW, AND L. STANLEY JAMES
}

Division of Perinatal Medicine, Departments of Pediatrics, Obstetrics and Gynecology, and Anesthesiology, College of Physicians and Surgeons, Columbia University, New York, New York 10032

\section{Summary}

Hypoxia is a potent stimulus to the release of vasopressin in fetal sheep, and plasma concentrations of the hormone correlate inversely with fetal oxygenation. Since the fetal kidney contributes to vasopressin clearance, we propose that measurement of

Received for publication September 19, 1983.

Address correspondence to Raymond I. Stark, M.D., Division of Perinatal Medicine. College of Physicians and Surgeons, Columbia University, New York, NY 10032.

This work was supported in part by Grant HD-13063 from the National Institutes of Health increased amounts of vasopressin in amniotic fluid would be indicative of fetal hypoxia. Therefore, we measured concentrations of vasopressin in amniotic fluid under resting conditions, during and after fetal hypoxia, and with intravenous and intraamniotic administration of vasopressin in 15 chronically instrumented fetal lambs between 111 and 141 days gestation. In the resting state, mean $( \pm \mathrm{SE})$ vasopressin concentrations in amniotic fluid $\left(1.6 \pm 0.3 \mathrm{pg} \mathrm{ml}^{-1}\right)$ did not differ from those in maternal $\left(1.4 \pm 0.4 \mathrm{pg} \mathrm{ml}^{-1}\right)$ or fetal $\left(1.8 \pm 0.2 \mathrm{pg} \mathrm{ml}^{-1}\right)$ plasma. Following exposure of the ewe to $10 \% \mathrm{O}_{2}$ or partial occlusion of the umbilical cord, vasopressin concentrations in fetal plasma in- 
creased significantly $(P<0.001)$ to $200 \pm 59 \mathrm{pg} \mathrm{ml}^{-1}$ with a delayed increase in amniotic fluid concentrations $(P<0.03)$ to $15.8 \pm 4.5 \mathrm{pg} \mathrm{ml}^{-1}$. This rise in concentration of vasopressin in amniotic fluid was sustained for at least $24 \mathrm{~h}$ and levels at that time were highly correlated with peak plasma concentrations $(r$ $=0.83 ; P<0.001)$. Intravenous infusion of vasopressin into the fetus was accompanied by an equally significant $(P<0.02)$ and sustained increase of vasopressin in amniotic fluid. Following intra-amniotic injection of vasopressin, levels remained increased for at least $24 \mathrm{~h}$.

Thus, in the third trimester of ovine gestation, amniotic fluid vasopressin concentration was a reliable indicator of prior fetal hypoxia. Parallel amounts of antidiuretic activity measured by bioassay and vasopressin measured by radioimmunoassay confirmed the presence of active hormone in amniotic fluid. Hypoxia alone was not a stimulus to passage of meconium, and increased concentrations of vasopressin in fetal plasma were not associated with expulsion of meconium in utero. Despite elevated concentrations of vasopressin in amniotic fluid, no associated changes in intrauterine pressure were discerned.

Evidence from a detailed review of long-term follow-up of infants by Paneth and Stark (19) supports the conclusion that asphyxia as indicated by clinical markers during the process of birth accounts for a smaller proportion of cerebral palsy and severe mental retardation than had been suspected. A major part of this discrepancy could be the result of asphyxial episodes occurring prior to the onset of labor. These episodes may not be reflected in the condition of the infant at birth, but could still lead to severe handicapping conditions. We have therefore endeavored to develop techniques for antipartum fetal surveillance.

Data from both animal and human studies have shown that hypoxic stress is a potent stimulus for the release of vasopressin as well as several other peptide hormones from the fetal pituitary. In the present study, we investigated the potential utility of the measurement of vasopressin concentration in the amniotic fluid as an index of hypoxic stress to the fetus during the last quarter of gestation in sheep.

Of further interest are the potential pathophysiologic consequences for the fetus of the release of vasopressin induced by hypoxia. De Vane et al. $(10,11)$ have suggested that increases in vasopressin during fetal asphyxia could be important in the fetal expulsion of meconium into the amniotic sac, thereby establishing the situation necessary for meconium aspiration. Still other investigators have proposed a role for vasopressin in the processes initiating labor $(5,17)$ and possibly the onset of premature delivery. Thus, in addition to assessment of vasopressin as a marker of hypoxia, we designed experiments to examine the relationship of the release of vasopressin by the fetus to the passage of meconium in utero and the stimulation of regular uterine contractions.

\section{MATERIALS AND METHODS}

Surgical Procedures. Fifteen mixed breed ewes of 95 to 105 days of gestation, defined by day of mounting, were acclimatized to the animal care facility and feed for at least 1 week prior to surgery. At 102 to 119 days of gestation, the animals were given spinal anesthesia with $10 \mathrm{mg}$ tetracaine. After cannulation of the maternal femoral artery and vein, anesthesia was supplemented with an IV infusion of $2 \mathrm{mg} \mathrm{m} \mathrm{m}^{-1}$ sodium thiopental in $5 \%$ dextrose (150-450 mg total dose). With appropriate sterile preparation and draping, the uterus was exposed through midline abdominal incision. The fetal neck was marsupialized to an antimesometrial portion of the uterine wall free of cotyledons of major vessels. Polyvinyl catheters were placed in the fetal carotid artery and jugular vein. Two polyvinyl catheters $(0.9 \mathrm{~mm}$ ID $\times$ $1.4 \mathrm{~mm}$ OD) with sumps fixed to the end to prevent occlusion by fetal membranes or particulate material were placed in the amniotic cavity and fixed to the fetal skin. Through a separate uterine incision, an inflatable silicon rubber cuff constrictor was placed around the umbilical cord. Care was taken to ensure that the constrictor did not occlude the umbilical cord in the deflated state. All catheters and activating tubing were tunneled subcutaneously and exteriorized into a pouch affixed to the ewe's flank. Benzathine penicillin ( 2.5 million units) was administered to the ewe on the day of surgery and ampicillin $\left(25 \mathrm{mg} \mathrm{kg}^{-1}\right)$ was given to the fetus and the ewe every $12 \mathrm{~h}$ for 3 days postoperatively. All vascular catheters were flushed on alternate days and filled with normal saline containing $200 \mathrm{U} \mathrm{ml}^{-1}$ heparin.

Condition of Animals. Experiments were conducted at least 6 days postoperatively. When more than one experiment was done on an animal, an interval of at least 6 days was allowed between studies. Prior to assignment to an experimental protocol, it was ascertained that fetal $\mathrm{pH}$ and blood gas tensions were within the normal range for our laboratory $\left(\mathrm{pH}_{a} 7.37 \pm 0.01 ; \mathrm{PaCO}_{2} 43.5 \pm\right.$ $0.9 \mathrm{~mm} \mathrm{Hg} ; \mathrm{PaO}_{2} 20 \pm 1.0 \mathrm{~mm} \mathrm{Hg}$ ). Eight ewes delivered lambs by spontaneous vaginal delivery at $144 \pm 1.2$ days (normal gestation in these animals is 148 days) and birth weight was 3.8 $\pm 0.2 \mathrm{~kg}$. Four fetuses died during labor or at unattended delivery at $144 \pm 1.4$ days, two of whom had umbilical cord occluders. Three fetuses died in utero at $131 \pm 2.5$ days, deaths occurring 2,5 , and 6 days after an experimental protocol.

Experimental Protocol. Pregnant ewes were maintained in portable pens with free access to feed and water throughout the study period. Amniotic fluid pressure was monitored continuously through one amniotic catheter with a Statham p $23 \mathrm{Db}$ (Hato Rey, Puerto Rico) strain gauge transducer and recorded on a Beckman Model 49 (Chicago, IL) paper chart recorder. Fetal heart rate was derived with a tachometer triggered from the blood pressure wave obtained and recorded with similar techniques. The animals were allowed at least $2 \mathrm{~h}$ to acclimatize to the study facility, prior to experimental interventions.

To examine the effects of fetal hypoxia on amniotic fluid vasopressin, ewes were given $10 \% \mathrm{O}_{2}$ in $\mathrm{N}_{2}$ to breathe for 30 min. The gas mixture was administered at flow rates of 6 to 8 liters $\mathrm{min}^{-1}$ into a specifically fitted head piece covered with a polyethylene bag taped loosely around the neck of the ewe. Results from these hypoxia studies were compared to control experiments conducted in a similar fashion except that room air was passed into the bag. To study the transfer of vasopressin from fetus to amniotic fluid, synthetic vasopressin (Parke-Davis, Morris Plains, NJ) in $0.9 \%$ saline was infused intravenously into the fetal jugular vein for $30 \mathrm{~min}$. The rate of infusion was $0.1 \mathrm{cc}$

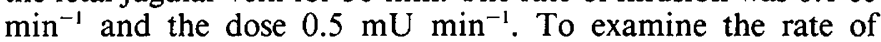
clearance of vasopressin from amniotic fluid, a bolus of synthetic vasopressin, 1 to $10 \mathrm{mU}$ in $2 \mathrm{ml}$ of $0.9 \%$ saline, was injected into the amniotic sac. Finally, to examine the rate of accumulation of endogenous fetal vasopressin in amniotic fluid as standardized in previous studies, the umbilical cord occluder was partially inflated until a 10 to $20 \%$ reduction in fetal heart rate was obtained and that degree of occlusion was maintained for $30 \mathrm{~min}$ (9). The number of studies and gestational age of the animals are summarized in Table 1.

Fetal arterial blood samples were drawn at 30 and $0 \mathrm{~min}$ before and $30,60,90$, and $120 \mathrm{~min}$, and $24 \mathrm{~h}$ after each of the above experiments. Amniotic fluid samples were obtained on the same schedule with additional samples at $3,4,6,18$, and $24 \mathrm{~h}$. The presence or absence of meconium in each sample was noted. Samples were not obtainable from all animals at all time intervals. If both amniotic fluid catheters were obstructed, they were flushed with $2.5 \mathrm{ml} 0.9 \%$ saline and the subsequent scheduled sample was obtained. It was only with an animal at greater than 135 days of gestation that this problem was encountered.

Biochemical Analysis. Samples of $2.5 \mathrm{ml}$ of blood and amniotic fluid were withdrawn anaerobically in heparinized syringes; $1.5 \mathrm{ml}$ was immediately transferred to chilled tubes containing EDTA for determination of vasopressin. Blood and amniotic fluid samples were centrifuged at $4^{\circ} \mathrm{C}$ for $20 \mathrm{~min}$ and plasma and amniotic fluid supernatant were stored at $-20^{\circ} \mathrm{C}$ until analyzed. The remainder of the blood sample was used for determination of $\mathrm{pH}, \mathrm{PCO}_{2}$, and $\mathrm{PO}_{2}$ with a Radiometer analyzer 
Table 1. Summary of experimental protocols, number of animals, and studies performed, and presence of meconium before and after a study

\begin{tabular}{|c|c|c|c|c|c|c|c|}
\hline & \multirow[b]{2}{*}{ Intervention } & \multicolumn{2}{|c|}{ Gestational age (days) } & \multirow[b]{2}{*}{ Animals $(n)$} & \multirow[b]{2}{*}{ Studies $(n)$} & \multicolumn{2}{|c|}{$\begin{array}{l}\text { Amniotic fluid } \\
\text { meconium }(n)\end{array}$} \\
\hline & & Mean & Range & & & Before & After \\
\hline Control & Room air $\times 30 \mathrm{~min}$ & $129 \pm 2.1$ & $124-136$ & 4 & 5 & 0 & 0 \\
\hline Hypoxia & $\begin{array}{l}10 \% \mathrm{O}_{2} \text { in } \mathrm{N}_{2} \times 30 \\
\min \end{array}$ & $128 \pm 2.0$ & $121-141$ & 10 & 16 & 2 & 3 \\
\hline Umbilical cord occlusion & $\begin{array}{l}\text { Partial inflation } \times \\
30 \mathrm{~min}\end{array}$ & $131 \pm 4.6$ & $123-139$ & 2 & 3 & 0 & 3 \\
\hline Intravenous vasopressin & $\begin{array}{l}0.5 \mathrm{mU} / \mathrm{min} \times 30 \\
\min \end{array}$ & $127 \pm 3.0$ & $111-138$ & 6 & 9 & 1 & 1 \\
\hline Intra-amniotic vasopressin & 1 to $10 \mathrm{mU}$ bolus & $128 \pm 4.3$ & $118-138$ & 4 & 5 & 0 & 0 \\
\hline
\end{tabular}

and microelectrodes. Base excess was subsequently calculated (30).

Vasopressin was extracted from $0.5 \mathrm{ml}$ of plasma with acetone and petroleum ether and measured by radioimmunoassay using methods that have been previously described $(14,31)$. The antibody employed in this assay has essentially no cross-reactivity with oxytocin or vasotocin. The method has a lower limit of sensitivity of better than $0.5 \mathrm{pg}$ tube ${ }^{-1}$ and an interassay variability of $8.4 \%$. The standards used in the assay were made from a synthetic arginine vasopressin obtained from Schwarz/Mann. Recovery of known amounts of vasopressin added before extraction was $67 \pm 4 \%$ and when added after extraction was $98 \pm$ $3 \%$.

Amniotic fluid vasopressin concentrations were determined by a modification of the plasma assay. Samples of $0.5 \mathrm{ml}$ were extracted with 2:1 acetone and dried under air. When vasopressin was added before extraction, recovery was $80 \pm 4 \%$. With 0.5 $\mathrm{ml}$ extracted amniotic fluid, the lower limit of sensitivity of the assay was $1.0 \mathrm{pg}$ tube $^{-1}$. Four pools of amniotic fluid containing $2,7,17$, and $28 \mathrm{pg} \mathrm{ml}^{-1}$ were assayed $\times 10$ in a single assay and gave an intra-assay variability of $8,4,3$, and $3 \%$, respectively. Two pools of amniotic fluid containing 4 and $25 \mathrm{pg} \mathrm{mi}^{-1}$ were assayed in six different assay runs and gave an interassay variability of 8 and $10 \%$, respectively. In general, all samples from a single experiment were analyzed in a single radioimmunoassay run.

To aid in establishing that the immunoreactive material in amniotic fluid was vasopressin, values determined by radioimmunoassay were compared with those obtained from the antidiuretic bioassay. Bioassays were kindly performed by Dr. Wilbur H. Sawyer, College of Physicians and Surgeons, Columbia University, using an alcohol-anesthetized rat antidiuretic assay (29). Three pools of amniotic fluid obtained following fetal hypoxia were used for this comparison.

Statistical Analysis. Data were expressed for purposes of summarization as mean \pm SEM except where otherwise indicated. Mean values were compared by one-way analysis of variance techniques to determine differences within experimental groups. The significance of differences at given time intervals was obtained using a modification of the Tukey transformation. Linear regression analysis using least mean squares methods was performed when correlating individual values. Finally, an unpaired $t$ test was used to compare mean values in control conditions. Standard techniques for determination of coefficient of correlation and per cent variation were also employed.

\section{RESULTS}

Resting Condition. In 13 animals, 59 matched samples of amniotic fluid and fetal plasma were obtained at 115 to 147 days of gestation. These samples were taken at least 5 days after any study protocol and animals were considered to be in a stable condition as defined by fetal pH 7.381 $\pm 0.005, \mathrm{PCO}_{2} 41.5 \pm 0.5$ $\mathrm{mm} \mathrm{Hg}$, and $\mathrm{PO}_{2} 22 \pm 0.9 \mathrm{~mm} \mathrm{Hg}$. The mean amniotic fluid vasopressin of $1.6 \pm 0.3 \mathrm{pg} \mathrm{ml}^{-1}$ (range, 0.5 to 7.5 ) did not differ significantly from fetal plasma vasopressin of $1.8 \pm 0.2$ (range,
0.5 to 6.0 ) or maternal plasma vasopressin of $1.4 \pm 0.4$ (range, 0.5 to 4.3 ). No differences in amniotic fluid or fetal plasma vasopressin were observed with advancing gestation.

Amniotic fluid $\mathrm{pH}$ determinations were made on 48 of these samples. The mean pH $6.89 \pm 0.04$ did not vary significantly with gestational maturation from 115 to 141 days of gestation, although there was a trend toward decreased $\mathrm{pH}$ close to term.

Experimental Conditions. Fetal arterial $\mathrm{pH}$, blood gas tensions, and base excess values during the various experimental protocols are summarized in Table 2. No significant differences were noted with exposure to room air (control) in contradistinction to the development of hypoxia and metabolic acidosis in the fetuses whose mothers were exposed to $10 \% \mathrm{O}_{2}$. In these fetuses, mean $\mathrm{PO}_{2}$ decreased significantly from $22.6 \pm 0.7$ to $13.2 \pm 0.6 \mathrm{~mm}$ $\mathrm{Hg}$ during the exposure while $\mathrm{pH}$ and base excess decreased both during and after the exposure. The only measurable change in $\mathrm{pH}$ or blood gas tensions with intravenous or intra-amniotic vasopressin administration was a significant increase in $\mathrm{PO}_{2}$ during IV vasopressin infusion.

Control and hypoxia studies were undertaken to measure changes of vasopressin concentration in amniotic fluid and fetal plasma and are summarized in Figure 1. Exposure of the ewe to room air for $30 \mathrm{~min}$ (control) was not associated with any distinct change in the concentration of vasopressin in either amniotic fluid or fetal plasma. Maternal plasma vasopressin values $1.3 \pm$ $0.2 \mathrm{pg} \mathrm{ml}^{-1}$ (range, 1.0 to 3.5 ) were equally stable.

Exposure of the ewe to $10 \% \mathrm{O}_{2}$ in $\mathrm{N}_{2}$ for $30 \mathrm{~min}$ (hypoxia) produced an increase of plasma vasopressin in all fetuses $(F=$ $9.00 ; P<0.001)$. There was a rapid decrease in mean concentrations during the 90 min following return to room air and $24 \mathrm{~h}$ later values were similar to those obtained prior to exposure (Fig. 1). Maternal plasma vasopressin concentrations increased in only one animal $\left(1.3\right.$ to $\left.4.0 \mathrm{pg} \mathrm{m}^{-1}\right)$ and the mean concentration during hypoxia $\left(1.8 \pm 0.6 \mathrm{pg} \mathrm{m}^{-1}\right)$ was not different from that preceding hypoxia $\left(1.5 \pm 0.4 \mathrm{pg} \mathrm{ml}^{-1}\right)$. Amniotic fluid concentrations of vasopressin increased in the hour following hypoxia and remained elevated at $24 \mathrm{~h}(F=3.26 ; P<0.03)$. Amniotic fluid vasopressin concentrations at both 4 and $24 \mathrm{~h}$ of recovery were highly correlated with peak fetal plasma concentrations $(r$ $=0.78, P<0.001$ and $r=0.83, P<0.001)$. When peak fetal and amniotic fluid concentrations were grouped with respect to gestational age at the time of hypoxia there was a trend toward increased mean values with advancing gestation; at 116 to 122 days $(n=6)$ fetal plasma mean was $124 \pm 58$ and amniotic fluid mean was $13.3 \pm 3.8 \mathrm{pg} \mathrm{ml}^{-1}$, at 125 to 129 days $(n=5) 171 \pm$ 79 and $18.2 \pm 8.7 \mathrm{pg} \mathrm{ml}^{-1}$, and at 134 to 141 days $(n=5) 345$ \pm 149 and $21 \pm 7.4 \mathrm{pg} \mathrm{ml}^{-1}$.

When vasopressin was infused into the fetal jugular vein at a dose of $0.5 \mathrm{mU} \mathrm{min}^{-1}$ for $30 \mathrm{~min}$, fetal plasma vasopressin concentrations after infusion ranged from 29 to $180 \mathrm{pg} \mathrm{ml}^{-1}$. The appearance of increased vasopressin concentrations $(F=$ $2.67 ; P<0.02)$ in amniotic fluid followed a pattern similar to that seen with hypoxia (Fig. 1). Mean maternal plasma vasopressin did not change, being $1.5 \pm 0.2,1.8 \pm 0.4$, and $1.5 \pm 0.4 \mathrm{pg}$ $\mathrm{ml}^{-1}$ before, during, and after infusion into the fetus, respectively. 
Table 2. Arterial pH, blood gas, and base deficit (BE) of fetal lambs at times before, during, and after control (exposure to room air $\times 30 \mathrm{~min}$ ) hypoxia (exposure to $10 \% \mathrm{O}_{2}$ in $\left.\mathrm{N}_{2} \times 30 \mathrm{~min}\right)$, intravenous infusion of vasopressin to the fetus $\left(0.5 \mu \mathrm{U} \mathrm{min} \mathrm{m}^{-1} \times 30 \mathrm{~min}\right)$, and intra-amniotic bolus injection of vasopressin ( 1 to $10 \mathrm{mU}$ ) (significant difference from contol, $P<0.01^{* *} ; P<0.05^{*}$ )

\begin{tabular}{|c|c|c|c|c|}
\hline & \multirow{2}{*}{$\begin{array}{c}\text { Before } \\
(-30 \mathrm{~min})\end{array}$} & \multirow{2}{*}{$\begin{array}{c}\text { During } \\
(+30 \mathrm{~min})\end{array}$} & \multicolumn{2}{|c|}{ After } \\
\hline & & & $(+60 \mathrm{~min})$ & $(+180 \mathrm{~min})$ \\
\hline \multicolumn{5}{|c|}{ Control (room air) } \\
\hline $\mathrm{pH}$ & $7.377 \pm 0.016$ & $7.370 \pm 0.017$ & $7.384 \pm 0.019$ & $7.379 \pm 0.015$ \\
\hline $\mathrm{PO}_{2}$ & $23.5 \pm 0.5$ & $24.6 \pm 0.6$ & $23.9 \pm 0.5$ & $24.5 \pm 0.6$ \\
\hline $\mathrm{PCO}_{2}$ & $43.9 \pm 1.1$ & $44.6 \pm 1.2$ & $41.0 \pm 0.7$ & $43.8 \pm 1.6$ \\
\hline $\mathrm{BE}$ & $+0.9 \pm 0.7$ & $-0.2 \pm 1.5$ & $-0.2 \pm 0.9$ & $+0.6 \pm 1.3$ \\
\hline \multicolumn{5}{|c|}{ Hypoxia $\left(10 \% \mathrm{O}_{2}\right)$} \\
\hline $\mathrm{pH}$ & $7.383 \pm 0.006$ & $7.352 \pm 0.022$ & $7.331 \pm 0.015^{*}$ & $7.361 \pm 0.016$ \\
\hline $\mathrm{PO}_{2}$ & $22.6 \pm 0.7$ & $13.2 \pm 0.6^{* *}$ & $24.5 \pm 1.4$ & $23.9 \pm 0.9$ \\
\hline $\mathrm{PCO}_{2}$ & $44.3 \pm 0.8$ & $41.8 \pm 2.6$ & $42.8 \pm 1.4$ & $42.1 \pm 1.0$ \\
\hline $\mathrm{BE}$ & $+0.6 \pm 0.6$ & $-2.2 \pm 1.3^{*}$ & $-3.2 \pm 1.0^{* *}$ & $-1.5 \pm 0.9$ \\
\hline \multicolumn{5}{|c|}{ Intravenous vasopressin } \\
\hline $\mathrm{pH}$ & $7.381 \pm 0.008$ & $7.379 \pm 0.009$ & $7.381 \pm 0.010$ & $7.373 \pm 0.010$ \\
\hline $\mathrm{PO}_{2}$ & $22.7 \pm 1.3$ & $25.4 \pm 2.0^{*}$ & $24.4 \pm 1.7$ & $24.2 \pm 1.1$ \\
\hline $\mathrm{PCO}_{2}$ & $41.2 \pm 0.7$ & $41.0 \pm 0.5$ & $41.4 \pm 0.9$ & $42.3 \pm 1.1$ \\
\hline $\mathrm{BE}$ & $-0.8 \pm 0.6$ & $-0.8 \pm 0.7$ & $-0.4 \pm 0.6$ & $-0.4 \pm 0.7$ \\
\hline \multicolumn{5}{|c|}{ Intra-amniotic vasopressin } \\
\hline $\mathrm{pH}$ & $7.383 \pm 0.007$ & $7.376 \pm 0.007$ & $7.373 \pm 0.007$ & $7.375 \pm 0.008$ \\
\hline $\mathrm{PO}_{2}$ & $22.6 \pm 1.3$ & $20.6 \pm 1.8$ & $22.1 \pm 1.4$ & $22.6 \pm 2.1$ \\
\hline $\mathrm{PCO}_{2}$ & $44.8 \pm 1.5$ & $44.9 \pm 1.1$ & $42.4 \pm 1.7$ & $42.9 \pm 1.3$ \\
\hline $\mathrm{BE}$ & $1.5 \pm 0.6$ & $1.2 \pm 1.0$ & $0.5 \pm 1.2$ & $0.2 \pm 0.7$ \\
\hline
\end{tabular}
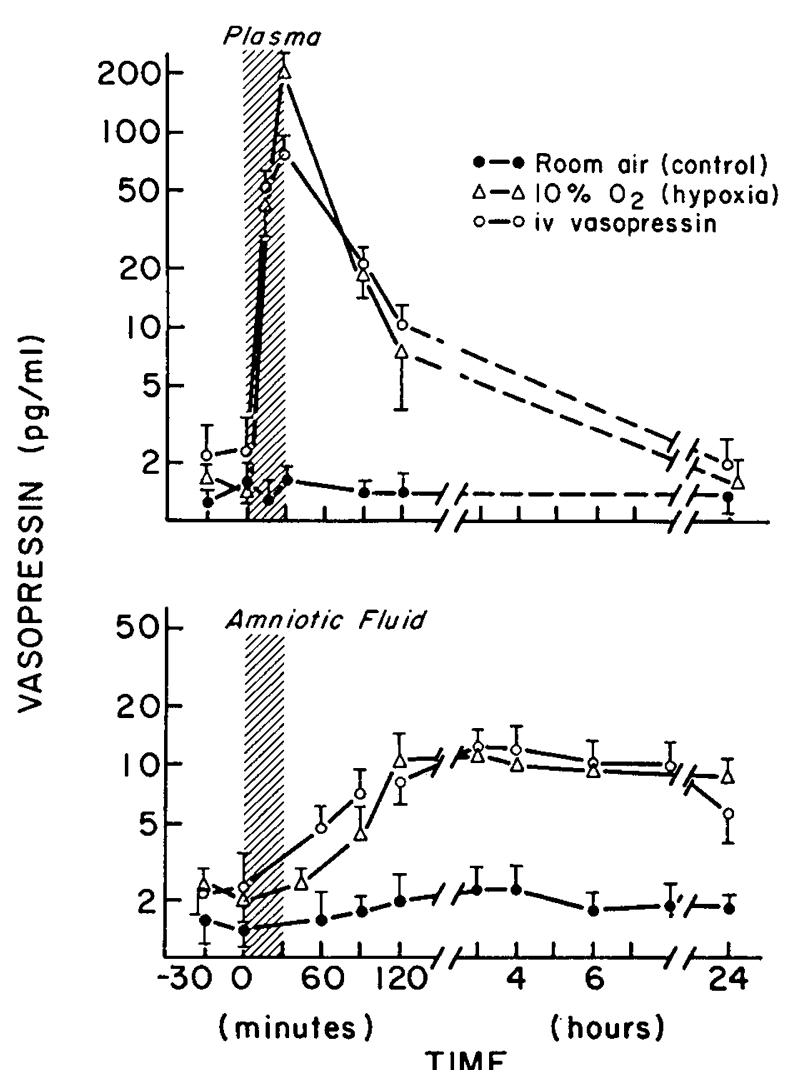

Fig. 1. Vasopressin concentrations (mean $\pm \mathrm{SE}$ ) in fetal plasma and amniotic fluid at times before, during (shaded bar), and after 30-min exposure to room air $(\bullet), 10 \% \mathrm{O}_{2}$ in $\mathrm{N}_{2}(\Delta)$, and intravenous vasopressin, $0.5 \mathrm{mU} \min ^{-1}(\mathrm{O})$.

Partial occlusion of the umbilical cord for $30 \mathrm{~min}$ not only caused a decrease from resting values of $\mathrm{PO}_{2}$ but also a large decrease in $\mathrm{pH}$ and base excess and increase in $\mathrm{PCO}_{2}$ (Table 3 ). This asphyxial stress was associated with a marked release of vasopressin into fetal plasma (Fig. 2). Vasopressin began to accumulate in amniotic fluid in the hour after occlusion and increased at a rate of $12.5 \mathrm{pg} \mathrm{h}^{-1}$ over the subsequent $3 \mathrm{~h}$.
Intra-amniotic injections of vasopressin were given to examine the pattern of disappearance of vasopressin from amniotic fluid (Fig. 3). Concentrations of vasopressin remained at a constant elevated level for at least $6 \mathrm{~h}$ after bolus doses ranging from 1 to $10 \mathrm{mU}$. Neither fetal $\left(1.8 \pm 0.6 \mathrm{pg} \mathrm{m}^{-1}\right)$ nor maternal $(1.4 \pm 0.3$ $\mathrm{pg} \mathrm{ml^{-1 }}$ ) plasma concentrations varied over this interval. At 24 $\mathrm{h}$ after injection, amniotic fluid vasopressin concentrations were consistently higher than those in the resting state.

The presence or absence of meconium in amniotic fluid before and $6 \mathrm{~h}$ after each study was determined macroscopically and observations are summarized in Table 1. No consistent pattern of meconium passage was observed except in those animals subjected to cord occlusion where meconium was found after but not before each study.

Intra-amniotic pressure was recorded for at least $2 \mathrm{~h}$ before and $6 \mathrm{~h}$ after each study. No discernible change in baseline intraamniotic pressure was defined except during and immediately following exposure of the ewe to $10 \% \mathrm{O}_{2}$ in $\mathrm{N}_{2}$. This increase in pressure was associated with maternal tachypnea and bleating. No sustained episodes of tonic increases in intra-amniotic pressure (uterine contractions) were recorded during the observation period in any animal. No animal delivered within 3 days of an experiment. A typical intra-amniotic pressure tracing during intravenous infusion of vasopressin to the fetus is shown in Figure 4 . There was no tendency toward increased intra-amniotic pressure despite large increases in the concentration of vasopressin in amniotic fluid.

\section{DISCUSSION}

The fetal hypothalamo-hypophyseal system is activated by hypoxia with release of both anterior and posterior pituitary hormones. Because of this, we proposed that measurements of the concentrations of peptide hormones in amniotic fluid might serve as indicators of fetal condition (Fig. 5). Vasopressin was chosen for evaluation as an indicator of fetal hypoxia because numerous investigators have described increased concentrations of the peptide in the umbilical cord blood of human infants $(5$, $11-13,20,21,23)$. Taken together, data from these studies suggest that fetal plasma vasopressin is elevated by the stress of labor and delivery. Although specific correlations were not apparent between Apgar score, $\mathrm{pH}$, or $\mathrm{PO}_{2}$ of umbilical arterial blood and concentrations of vasopressin in our group (21), most 
Table 3. Arterial pH, blood gas tension, and base excess before and after a 30-min partial occlusion of the umbilical cord in the fetal lamb at three gestational ages

\begin{tabular}{|c|c|c|c|c|c|c|c|c|c|}
\hline \multirow[b]{2}{*}{ Animal } & \multirow{2}{*}{$\begin{array}{c}\text { Gestational } \\
\text { age (days) }\end{array}$} & \multicolumn{2}{|c|}{$\mathrm{pH}$} & \multicolumn{2}{|c|}{$\mathrm{PO}_{2} \mathrm{~mm} \mathrm{Hg}$} & \multicolumn{2}{|c|}{$\mathrm{PCO}_{2} \mathrm{~mm} \mathrm{Hg}$} & \multicolumn{2}{|c|}{ Base excess } \\
\hline & & Before & After & Before & After & Before & After & Before & After \\
\hline 1 & 123 & 7.370 & 7.067 & 22 & 14 & 42 & 80 & -1.0 & -13.0 \\
\hline 2 & 131 & 7.399 & 6.870 & 21 & 11 & 47 & 117 & +3.8 & -15.9 \\
\hline 3 & 139 & 7.397 & 7.125 & 23 & 14 & 46 & 58.5 & +3.0 & -12.1 \\
\hline
\end{tabular}

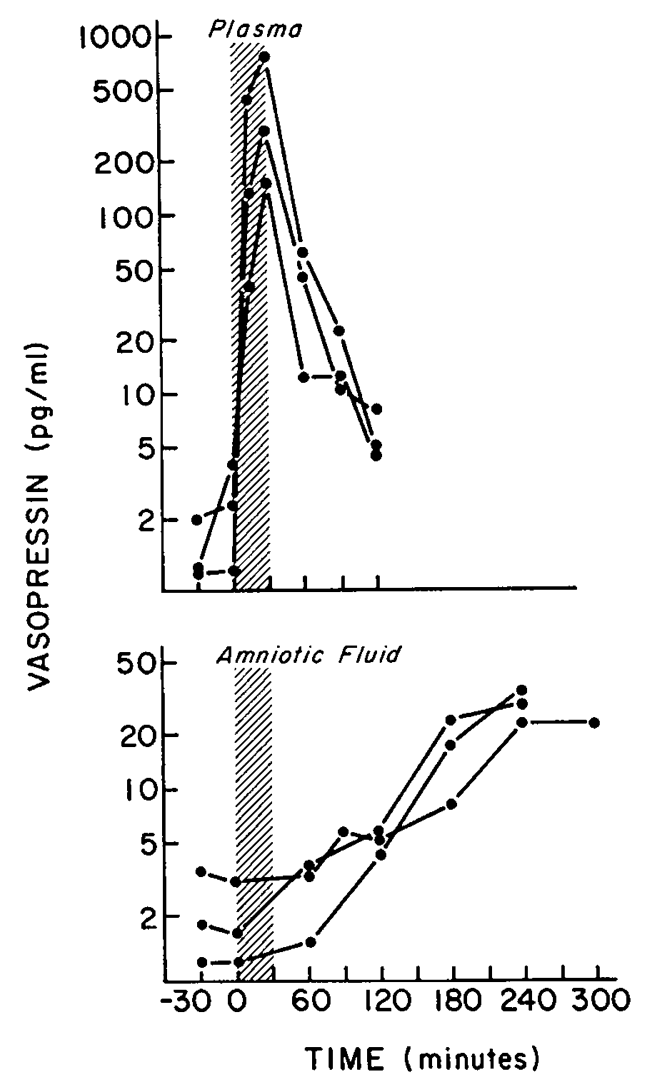

Fig. 2. Vasopressin concentrations in fetal plasma and amniotic fluid at times before, during (shaded bar), and after 30-min partial occlusion of the umbilical cord.

investigators presumed that hypoxia was a major stimulus to vasopressin release. The validity of this presumption has been clearly demonstrated in the fetal lamb $(2,9,10,24,28,33)$ where hypoxia alone or in combination with asphyxia was found to be a potent stimulus to release of vasopressin by the fetus. Increases in fetal plasma vasopressin concentrations were strongly correlated with decreases in $\mathrm{PO}_{2}$ and $\mathrm{pH}(28,33)$. Other stressful processes including umbilical cord occlusion (9), fetal hemorrhage $(1,25)$, decreased uterine perfusion (10), and fetal hypotension (26) have equally been associated with increased concentrations of vasopressin in fetal plasma. We found both spontaneous and prematurely induced labor to be potent stimuli to fetal vasopressin secretion $(31,32)$ levels rising only after the onset of labor. Finally, we have recently demonstrated that during and after hypoxia renal excretion of vasopressin increases 10 - to 20 -fold (8). Thus, existing data strongly suggest that measurement of amniotic fluid vasopressin concentrations would serve as an index of fetal hypoxia.

In the present study, we found that concentrations of vasopressin in amniotic fluid of sheep rose following fetal hypoxia (Fig. 1). The time course of change in concentrations of vasopressin in fetal plasma and delayed accumulation in amniotic fluid follows a pattern expected of a hormone released into the fetal plasma and excreted with fetal urine into the amniotic cavity (Fig. 5). It is noteworthy that although the serum of

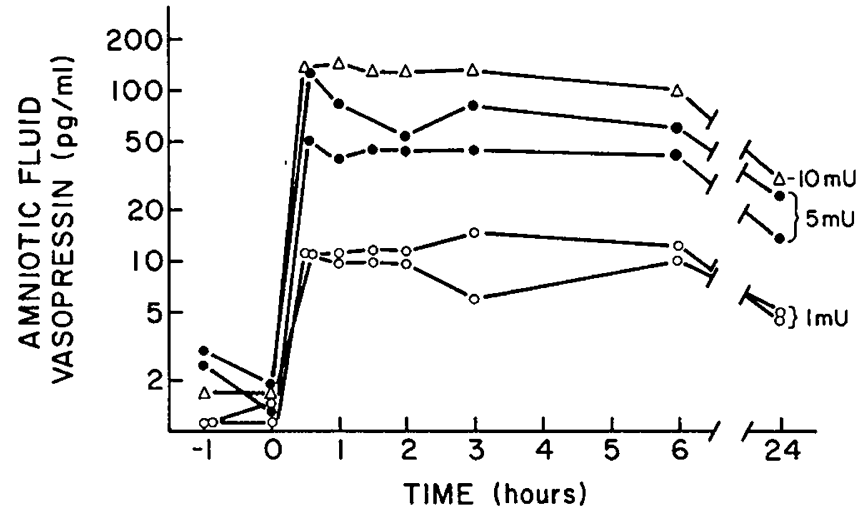

Fig. 3. Vasopressin concentrations in amniotic fluid before and after a bolus injection of synthetic vasopressin into the amniotic sac. Dosages are indicated on the right.

pregnant woman was found to contain increasingly large amounts of vasopressinase activity as gestation advances, umbilical cord plasma and amniotic fluid have several orders of magnitude less activity (27). Vasopressinase activity, a measure of the degradation of vasopressin, is not detectable in the plasma or amniotic fluid of sheep (27). In the absence of intrinsic mechanisms for enzymatic degradation, we found that increased concentrations of vasopressin in sheep amniotic fluid persist for at least $24 \mathrm{~h}$. Thus, we have data confirming the validity of the measurement of vasopressin as an index of fetal hypoxia in sheep. Further, studies are in progress to confirm the utility of this measurement and that of other products of the hypothalamohypophyseal system in human pregnancy.

The potential pathogenic consequences to the fetus of vasopressin released as a result of hypoxia have been examined from several points of view. With data derived from the umbilical cord plasma of human fetuses, DeVane and Porter (11) have described markedly increased concentrations of vasopressin following intrauterine bradycardia and meconium passage in utero. These data led them to conclude that passage of meconium in utero might be mediated by vasopressin released by the asphyxiated fetus. In subsequent studies with the fetal lamb, they report meconium passage into the amniotic sac during profound asphyxial stress but not with milder forms of oxygen deprivation (10). In the present experiments, no consistent pattern of meconium passage was observed with moderate fetal hypoxia induced by exposure of the ewe to $10 \% \mathrm{O}_{2}$. More severe hypoxia and asphyxia achieved by umbilical cord occlusion was associated with meconium passage (Table 3 ). However, if the in utero passage of meconium were mediated by an increase in circulating vasopressin, as has recently been suggested by Wiriyathian et al. (37), then passage of meconium might be expected with intravenous infusion of vasopressin to the fetus. We found no such association. Despite 10- to 100 -fold increases in fetal plasma vasopressin, levels comparable to those attained with umbilical cord occlusion, amniơtic fluid remained free of meconium, unless meconium were present prior to the study (Fig. 3 and Table 1). These discrepancies may be related to the consistency of sampling following hypoxia or to differences in the gestational age of the animals. Nevertheless, these observations support the long held clinical conviction of obstetricians that meconium 


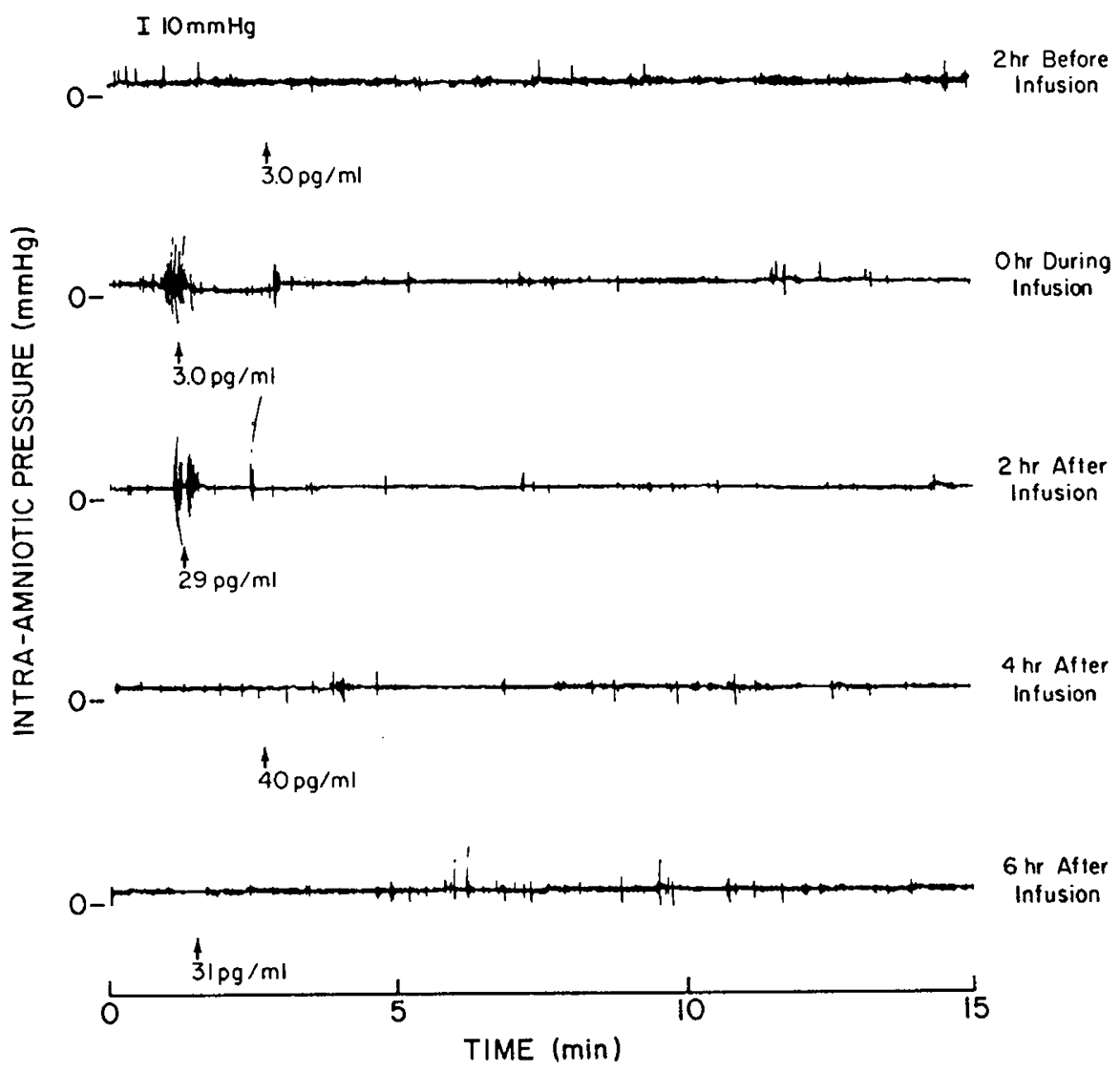

Fig. 4. Representative changes in intra-amniotic pressure $(\mathrm{mm} \mathrm{Hg})$ in $15-\mathrm{min}$ epochs before, during, and after intravenous vasopressin infusion

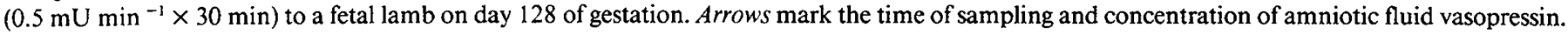

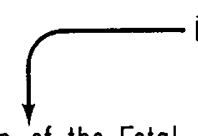

Activation of the Fetal Hypothalamo-Hypophyseal<smiles>[3H][AsH3]1CC[AsH2]1</smiles>

Hormone Secretion

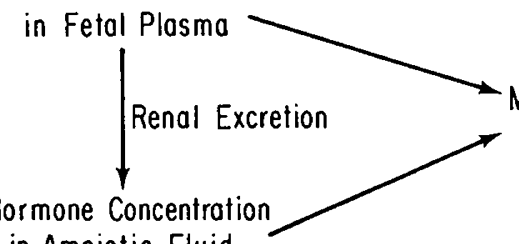

in Amniotic Fluid

Fig. 5. Rationale for measurement of hypothalamo-hypophyseal hormones in fetal plasma at birth and amniotic fluid during gestation.

passage is an indication of fetal distress, but deny a role for vasopressin in the mechanisms leading to meconium passage.

Two mechanisms have been suggested by which fetal vasopressin may exert an effect on the initiation or maintenance of parturition. First, the activity of corticotropic peptides released from fetal pituitary is thought to be of central importance in the triggering mechanism of parturition in sheep; yet the definition of the specific tropic factor or factors remains controversial as does the importance of maturation of fetal adrenal sensitivity to tropic stimulation (4). Nonetheless, vasopressin has recently been shown to potentiate the activity of corticotropin-releasing factor with respect to adrenocorticotropin release (35). Thus, enhanced vasopressin release by the hypoxic fetus has the potential to function in an ancillary role in the cascade of events leading to labor. Adding further credence to the possibility is our recent demonstration that not only plasma but also cerebrospinal fluid concentration of vasopressin is increased by fetal hypoxia (34). The transient increases in fetal plasma vasopressin concentrations achieved by hypoxic stimulation or intra-venous infusion in the present study had no demonstrable effect on uterine activity as measured by the absence of induced preterm parturition. What effect protracted stimulation of vasopressin secretion might have remains to be determined.

Alternately, vasopressin might stimulate uterine contractility indirectly. Vasopressin has the capacity to enhance the synthesis of prostaglandins (22) and prostaglandin generation in the amniotic membranes and decidua is thought to be the final common pathway for initiation of labor (15). The present experiments have defined a means by which fetal vasopressin can gain access to the fetal membranes. However, even 100-fold increases in amniotic fluid vasopressin concentration sustained for at least $24 \mathrm{~h}$ had no demonstrable effect on myometrial activity as measured by intra-amniotic pressure.

Finally, there have been few experiments examining the humoral factors influencing amniotic fluid volume and composition. Work by ourselves and others suggests that the fetal neurohypophysis participates in the maintenance of fetal osmolar and volume homeostasis through action on the fetal kidney and urinary concentration mechanisms $(7,36)$, thereby affecting amniotic fluid dynamics. Furthermore, vasopressin has been shown to have a direct effect on water metabolism of the amniotic membranes (16). Data from the present study demonstrate the release of significant amounts of biologically active vasopressin into amniotic fluid following fetal hypoxia. The humoral mechanism regulating amniotic fluid volume and composition may include a role for vasopressin and may be altered by fetal hypoxia. 


\section{REFERENCES}

1. Alexander DP, Britton HG, Forsling ML, Nixon DA, Ratcliff JGL 1974 Pituitary and plasma concentrations of adrenocorticotropin, growth hormone, vasopressin and oxytocin in fetal and maternal sheep during the latter half of gestation and response to hemorrhage. Biol Neonate 21:206

2. Alexander DP, Forsling ML. Martin MJ, Nixon DA, Ratcliffe JG, Redstone D, Tunbridge D 1972 The effect of maternal hypoxia on fetal pituitary hormone release in sheep. Biol Neonate 21:219

3. Bennebroek Grovenhorst J, Wiseman PF 1968 Hydramnios treated by intraamniotic administration of antidiuretic hormone. J Obstet Gynecol $\mathrm{Br}$ Commonw 75:1072

4. Challis JRG, Mitchell BF 1981 Hormonal control of preterm and term parturition. Semin Perinatol 5:192

5. Chard T 1972 The posterior pituitary in human and animal parturition. $J$ Reprod Fertil Suppl 16:121

6. Chard T, Hudson CN. Edwards CRW, Boyd NRH 1971 The release of oxytocin and vasopressin by the human foetus during labor. Nature (Lond) 234:352

7. Daniel SS, Stark RI, Husain MK, Baxi LS, James LS 1982 Role of vasopressin in fetal homeostasis. Am J Physiol 242:F740

8. Daniel SS, Stark RI. Husain MK, Sanocka UM, James LS 1984 Excretion of vasopressin in the hypoxic lamb: comparison between fetus and newborn. Pediatr Res, 18:227

9. Daniel SS, Yeh M-N, Bowe ET, Fu Kunaga A, James LS 1975 Renal response to partial occlusion of the cord. J Pediatr 87:788

10. DeVane GW, Naden RP, Porter JC, Rosenfeld CR 1982 Mechanism of arginine vasopressin release in the sheep fetus. Pediatr Res 16:504

11. DeVane GW, Porter JC 1980 An apparent stress-induced release of arginine vasopressin by human neonates. J Clin Endocrinol Metab 51:1412

12. Hadeed AJ, Leake RD, Weitzman RE, Fisher DA 1979 Possible mechanisms of high blood levels of vasopressin during the neonatal period. J Pediatr 94:805

13. Hoppenstein JM, Miltenberger OW, Moran WH Jr 1968 The increase in blood levels of vasopressin in infants during birth and surgical procedures. Surg Gynecol Obstet 127:966

14. Hussain MK, Fernando N, Shapiro M, Kagan A, Glick SM 1973 Radioimmunoassay of arginine vasopressin in human plasma. J Clin Endocrinol Metab 37:616

15. MacDonald PC, Porter JC. Schwarz BE, Johnston JM 1978 Initiation of parturition in the human female. Semin Perinatol 2:273

16. Manku MS, Mgabuju JP, Horrobin DF 1975 Effect of cortosiol, prolectin, and ADH on amniotic membrane. Nature (Lond) 258:78

17. Mellors DJ, Slater JS 1974 Some aspects of the physiology of sheep foetal fluids. Br Vet J 130:238

18. Nathanielsz PW, Yu HK, Cabalum TC 1982 Effect of abolition of fetal movements on fetal intravascular $\mathrm{PO}_{2}$ and incidence of tonic myometrial contractures in the pregnant ewe at 114 to 134 days gestation. Am J Obstet Gynecol 144:614

19. Paneth N, Stark RI 1983 Birth asphyxia, cerebral palsy and mental retardation: an epidemiologic overview. Am J Obstet Gynecol 147:960

20. Pohjavouri M, Fyhrquist F 1980 Hemodynamic significance of vasopressin in the newborn infant. J Pediatr 97:462

21. Polin RA, Husain MK, James LS, Frantz AG 1977 High vasopressin concentrations in human umbilical cord blood-lack of correlation with stress. J Perinat Med 5:114

22. Pugliese F, Sato M. Williams S, Masamichi A, Hassid A, Dunn M 1983 Rabbit and rat renal papillary collection tubule cells in culture: the interactions of arginine vasopressin, prostaglandins, and cyclic AMP. In: (Samuelsson R, Paoletti R, Ramwell P (eds) Advances in Prostaglandin, Thromboxane, and Leukotriene Research. New York, Raven Press, vol II, pp 517-523

23. Rees L, Forsling ML, Brook CGD 1980 Vasopressin concentrations in the neonatal period. Clin Endocrinol 12:357

24. Robillard JE. Weitzman RE, Burmeister L, Smith FG Jr 1981 Developmental aspects of the renal responses to hypoxemia in the lamb fetus. Circ Res 48:128

25. Robillard JE, Weitzman RE, Fisher DA, Smith FG Jr 1979 The dynamics of vasopressin release and blood volume regulation during fetal hemorrhage in the lamb fetus. Pediatr Res 13:606

26. Rose JC, Meis PJ, Morris M 1981 Ontogeny of endocrine (ACTH, vasopressin and cortisol) response to hypertension in lamb fetuses. Am J Physiol 240:E656

27. Rosenbloom AA, Sack J, Fisher DA 1975 The circulating vasopressinase of pregnancy: species comparison with radioimmunoassay. Am J Obstet Gynecol 121:316

28. Rurak DW 1978 Plasma vasopressin levels during hypoxemia and cardiovascular effects of exogenous vasopressin in foetal and adult sheep. J Physiol (Lond) $277: 341$

29. Sawyer WH 1958 Differences in antidiuretic responses of rats to the intravenous administration of lysine and arginine vasopressins. Endocrinology 63:694

30. Siggard Anderson O 1963 Blood acid-base alignment nomogram. Scand J Clin Lab Invest 15:211

31. Stark RI, Daniel SS, Husain MK, James LS, Vande Wiele RL 1979 Arginine vasopressin during gestation and parturition in sheep fetus. Biol Neonate $35: 235$

32. Stark RI, Daniel SS, Husain MK, Milliez J, Morishima HO, James LS, Vande Wiele RL 1981 Release of vasopressin by the fetal lamb during premature parturition induced by corticotropin. Pediatr Res 15:1261

33. Stark RI, Wardlaw SL, Daniel SS, Husain MK, Sanocka UM, James LS, Vande Wiele RL 1982 Vasopressin secretion induced by hypoxia in sheep: developmental changes and relationship to $\beta$-endorphin release. Am J Obstet Gynecol 143:204

34. Stark RI. Daniel SS, Husain MK, Zubrow AB, James LS 1983 Changes in fetal plasma and cerebrospinal (CSF) vasopressin (VP) with hypoxia. Pediatr Res 17:172A

35. Turkelson CM. Thomas CR, Arimura A, Chang D, Chang JK, Shimizu 1982 The in vitro potentiation of activity of synthetic ovine corticotropin-releasing factor by arginine vasopressin. Peptides 3:111

36. Wintour EM, Congiu M. Hardy KJ, Hennessy DP 1982. Regulation of urine osmolality in fetal sheep. Q J Exp Physiol 67:427

37. Wiriyathian S, Porter JC, Naden RP, Rosenfeld CR 1983 Cardiovascular effects and clearance of exogenous arginine vasopressin (AVP) in the fetal lamb. Am J Physiol 245:E24 